\title{
NARRATIVAS ÉTNICAS CONFLUENTES EM LITERATURAS DAS AMÉRICAS
}

TOSTA, Antonio Luciano de Andrade. Confluence Narratives: Ethnicity, History, and Nation-Making in the Americas. Lewisburg: Bucknel University Press, 2016. 314 p.

A obra aqui resenhada se inscreve no campo de investigação de uma identidade americana nascida do encontro de culturas diferenciadas. É longa a lista de pesquisadores que se voltam para o exame de um comparatismo literário que, longe de buscar as influências das mães-pátrias, partem para observar o dinamismo cultural gerado na literatura do Novo Mundo. Exemplo desse gênero de pesquisa são as coletâneas organizadas por Zila Bernd e outra por mim, que mapeiam o imaginário coletivo do continente americano por meio de levantamentos de figuras míticas que passaram por processos variados de transformações, produzindo fenômenos específicos de mestiçagem e hibridismo. ${ }^{1}$

Lançando mão do conceito de confluência (confluence), Luciano Tosta, professor da Universidade de Kansas, enfatiza a importância de um campo étnico, negligenciado pela história convencional, capaz de revelar manifestações culturais tornadas invisíveis durante séculos. Tais manifestações, empreendidas por grupos marginalizados, formam igualmente o corpo das nações que se desenvolveram no continente americano. Essas manifestações engendraram

1 Zila Bernd (org.), Dicionário de figuras e mitos literários das Américas, Porto Alegre: Tomo Editorial; Editora da Universidade, 2007; e Licia S. de Souza (org.), Dicionário de personagens afrobrasileiros, Salvador: Quarteto Editora, 2009. 
narrativas aptas a flagrar as conexões intergrupais cujo enfoque multidisciplinar permite vislumbrar contribuições imprevisíveis para a emergência de um desejado Novo Mundo. Trata-se de um mundo reterritorializado, cujo espaço geográfico assistiu a inúmeras experiências de diásporas, migrações e intercâmbios culturais suscetíveis de reconfigurar a natureza simbólica das nações emergentes. Nesse caso, a ideia de nação se destaca como um território móvel e maleável, aberto a sempre novos protocolos de comunicação e pactos de ressignificação, prontos a fazer conhecer as mobilidades culturais que se têm efetuado desde a colonização.

A visão das figuras identitárias como lugares de confluência do múltiplo determina a concepção de uma narrativa como espaço de desestabilização, permitindo caminhos transversais. São entrecruzamentos de discursos que dão origem à escrita híbrida, com resultados propensos às experiências de transculturação. As literaturas hibridizadas, que constituem conjuntos plurais por excelência, promovem quadros de referência com valores acrescidos de imprevisibilidade e intervalorização de culturas mestiçadas.

Na história recente do Brasil, as confluências narrativas foram prejudicadas pela ditadura militar dos anos 1960, segundo o autor, a qual privilegiava apenas uma visão autoritária de cultura, a dos colonizadores. Nos anos 1980, entretanto, a América Latina no seu conjunto passou a repensar os projetos nacionais, buscando o dinamismo polifônico dos grupos sociais e recusando as visões hegemônicas em cada nação. Em cada capítulo de seu livro, Tosta compara um romance brasileiro com um de outro país das Américas: México, Estados Unidos, Argentina e Canadá. Cada capítulo é antecedido de uma introdução, que contextualiza historicamente o grupo étnico específico ali analisado. É fundamental também para a análise do pesquisador brasileiro radicado nos Estados Unidos o papel da história na construção da narrativa da nação. O autor estuda oito romances históricos, revelando como as trajetórias desses diversos e fundamentais grupos étnicos são parte essencial da história nacional; ou melhor, das histórias das duas nações presentes no exercício comparativo, conectadas por processos 
históricos como colonização, escravidão ou imigração. Nessa concepção reside a originalidade desta obra de Luciano Tosta.

No capítulo 1, "The Native American, Hibridity, and Mestiçagem in Luiz Antonio de Assis Brasil's Breviário das Terras do Brasil and Laura Esquivel's Malinche”, o autor analisa a representação de dois protagonistas ameríndios, um brasileiro, outro mexicano. Trata-se de examinar, de um lado, como a configuração dos personagens evidencia mecanismos do processo colonizador homogeneizante das Américas. Por outro lado, o autor destaca a posição de exclusão do ameríndio na história nacional dos países visados. O capítulo não deixa, entretanto, de mostrar a força das formações culturais indígenas que os empodera e reforça suas imagens como grandes protagonistas das nações americanas.

No capítulo 2, "Escaping the Nation? African American History as (Trans)National History in Luis Fulano de Tal's A Noite dos Cristais and Ishmael Reed's Flight to Canada", são investigadas as formas como os autores destacam aspectos fundamentais do papel que os afrodescendentes desempenharam em cada história nacional, Brasil e Estados Unidos. A escravidão permitiu um movimento pan-africano apto a forjar as identidades construídas no compartilhamento das origens dos escravizados. O capítulo explora a natureza complexa das origens africanas e o legado cultural que conecta as Américas a uma África miticamente construída, o que tem unido afro-americanos, durante séculos, nas nações modernas do continente, nas quais a cor da pele tem sido objeto de discriminação, mas signo igualmente de resistência. Uma forte reflexão se desenrola sobre como os dois autores discutem políticas de identidade e políticas de reconhecimento das contribuições dos grupos afrodescendentes para a formação da nação.

No capítulo 3, "Jewish Puzzles: Identity Search, Memory and History in Moacyr Scliar's A Estranha Nação de Rafael Mendes and Ricardo Feierstein's Mestizo" - um autor judeu brasileiro e outro judeu argentino - a identidade judaico-americana é salientada através de dois personagens que buscam traços de um passado ancestral para construir uma identidade individual e cultural. Os romances exibem a complexidade da condição híbrida que permite uma 
identidade do entredois. São duas narrativas de confluência que fornecem exemplos fundamentais de como a transnacionalização judaica tem gerado grandes acontecimentos históricos na humanidade. Os romances acentuam que o povo judeu tem contribuído, de forma bastante significativa, para as formações nacionais, mesmo sendo, de forma paradoxal, vistos como estrangeiros.

No capítulo 4, "Word War II and the Persecution of Identity: Memory, Difference, and the Struggle for Belonging in Jorge J. Okubaro's O Súdito: (Banzai, Massateru!) and Joy Kowaga's Obasan”, o autor examina como esses dois romances trabalham problemáticas da existência dos imigrantes japoneses no Brasil e no Canadá durante a Segunda Guerra Mundial. O capítulo realça os efeitos da participação do Japão na guerra em seus imigrantes nas Américas, revelando como eles produziram conflitos de identidade. Debate como a guerra acentuou a percepção da "alteridade” e das diferenças nas Américas, se tornando mais uma dificuldade para a inclusão dos japoneses, física e imaginária, na nação de destino. A obra de Okubaro acentua, de forma significativa, a representação do cenário de diversidade produzido pela imigração, e os dilemas de um duplo pertencimento que vão desde os movimentos de resistência à assimilação linear aos esforços para suplantá-la de forma dialética.

Luciano Tosta conclui refletindo sobre a natureza da confluência narrativa como método profícuo de abordagem para se entender a formação da nação moderna. O diálogo entre as culturas, com suas histórias e tradições, é privilegiado para assinalar o feixe de relações que torna possível a emergência das comunidades novas das Américas. É o que garante um comparatismo literário dinâmico, capaz de pôr em primeiro plano as formações míticas produzidas nos territórios americanos, sem a busca de relações de influência pelas pátrias colonizadoras europeias.

\section{Licia Soares de Souza (D)}

Universidade do Estado da Bahia 